individual, a group, a firm, or other organization.

If possible, nominations should be accompanied by photocopies of reviews evaluating the works nominated and statements from the nominee about why the work should be considered.

Nominations should be sent to Professor Thomas P. Stevens, Chairperson, Dartmouth Medal Committee, Reference and Adult Services Division, c/o School of Library Science, University of Michigan, Ann Arbor, MI 48109.

Nominations should be submitted by January 16,1978 , so that they may be screened when the Dartmouth Medal Committee meets during Midwinter. The final deadline for receiving nominations, however, will be March 15, 1978.

The award will be presented at ALA's Annual Conference in Chicago in 1978. In the case of shared responsibility for creation of a work, duplicate awards will be presented.

This award is made possible by Dartmouth College in Hanover, New Hampshire. The medal was designed by Rudolph Ruzicka, the celebrated graphic artist. The modeling for the dies was made by Joseph DiLorenzo, and the medal was struck by the Metalic Art Company of Danbury, Connecticut.

\title{
ACRL at the 1977 Annual Conference
}

More than twenty program sessions were sponsored by ACRL and its various units during the 1977 ALA Annual Conference in Detroit. ACRL's principal program was a speech delivered by Stephen K. Bailey, acting president of the American Council on Education. Dr. Bailey's address, "The Future of College and Research Libraries: A Washington Perspective," will be published in College \& Research Libraries.

ACRL section programs afforded opportunities for members to update their knowledge of all aspects of academic and research librarianship: collection development, bibliographic instruction, reference service, communication and cooperation, coping with change, national bibliography, statistics, and rare books and manuscripts. ACRL's discussion groups provided a forum for communication among librarians with specialized interests. Tours sponsored by ACRL units included visits to the Henry Ford Museum and Greenfield Village, a view of Slavic collections and sights in the Detroit area, and an architectural tour of Detroit buildings.

ACRL President Connie R. Dunlap presided at ACRL's membership meeting, at which ACRL's newly elected officers were introduced. George R. Parks, conference chair for ACRL's 1978 National Conference in Boston, announced the conference theme, "New Horizons for Academic Libraries," and urged all members to contribute papers for the conference. ACRL members approved the proposed amendment to the ACRL Constitution and Bylaws to provide for the publications programs of ACRL.

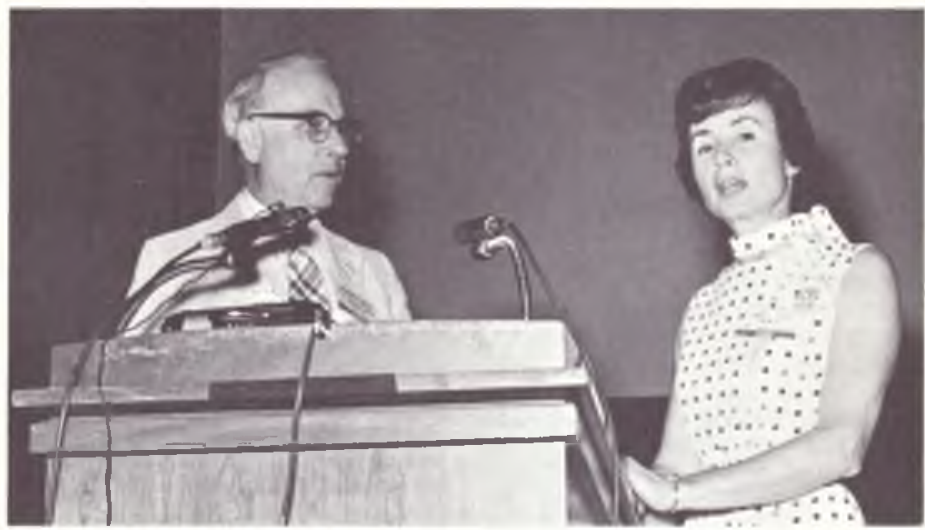

Stephen K. Boiley and Connie R. Dunlap. 